\title{
Abbreviations and select bibliography
}

Only editions, monographs, and journal articles cited in the study are listed.

\author{
Abbreviations \\ AV \\ Authorised Version (1611 English edition of the Bible). This is the \\ version always used in references and quotations unless otherwise \\ noted. \\ Douay See Vulgate. \\ EETS ES Early English Text Society Extra Series. \\ EETS OS Early English Text Society Original Series. \\ MED Middle English Dictionary, ed. H. Kurath and others (Ann Arbor: \\ Michigan University Press, 1954-2002). \\ OED Oxford English Dictionary. \\ Vulgate The Latin Vulgate Bible, Biblia Sacra, cited in the Douay \\ translation.
}

\section{Editions of the Gawain-poems}

Sir Gawain and the Green Knight, Pearl, Cleanness, Patience, ed. J. J. Anderson (London: Dent, Everyman, 1996). All references to and quotations from the Gawain-poems are based on this edition.

The Poems of the Pearl Manuscript: Pearl, Cleanness, Patience, Sir Gawain and the Green Knight, ed. M. Andrew and R. A. Waldron, 2nd edn (Exeter: Exeter University Press, 2002).

The Pearl Poems: An Omnibus Edition, ed. William Vantuono, 2 vols (New York, 1984).

Pearl, ed. E. V Gordon (Oxford: Oxford University Press, 1953).

Purity [Cleanness], ed. Robert J. Menner (New Haven: Yale University Press, 1920).

Patience, ed. J. J. Anderson (Manchester: Manchester University Press, 1969).

Sir Gawain and the Green Knight, ed. J. R. R. Tolkien and E. V. Gordon, 2nd edn rev. N. Davis (Oxford: Oxford University Press, 1967). 


\section{Editions of other texts}

The Alliterative Morte Arthure in King Arthur's Death, ed. Larry D. Benson, rev. Edward E. Foster (Kalamazoo: Medieval Institute Publications, 1994).

Barlam and Iosaphat, ed. John C. Hirsh, EETS OS 290 (London: Oxford University Press, 1986).

The Bestiary, in J. A. W. Bennett and G. V. Smithers, eds, Early Middle English Verse and Prose (London: Oxford University Press, 1966), pp. 171-3.

Sermons of Thomas Brinton, ed. M. A. Devlin, 2 vols, Camden Society 3rd series 85, 86 (London: Royal Historical Society, 1954)

Chaucer, Geoffrey, The Canterbury Tales, The Book of the Duchess, in The Riverside Chaucer, ed. L. D. Benson and others, 3rd edn (Boston: Houghton Mifflin, 1987). All references to and quotations from Chaucer's works are based on this edition.

Gower, John, The English Works of Fohn Gower, ed. G. C. Macaulay, 2 vols, EETS ES 81, 82 (London: Oxford University Press, 1900, 1901).

The Harley Lyrics, ed. G L. Brook, 3rd edn (Manchester University Press, 1964).

Langland, William, Piers Plowman, B-text, ed. A. V. C. Schmidt, 2nd edn (London: Dent, Everyman, 1995).

Malory, Sir Thomas, Works, ed. Eugene Vinaver, 2nd edn (Oxford: Oxford University Press, 1977).

Pecock, Reginald, Reule of Crysten Religion, ed. W. C. Greet, EETS OS 171 (London: Oxford University Press, 1927).

The Quest of the Holy Grail, trans. P. M. Matarasso (London: Penguin, 1969).

Sawles Warde, in J. A. W. Bennett and G. V. Smithers, eds, Early Middle English Verse and Prose (London: Oxford University Press, 1966), pp. 246-61.

Speculum Sacerdotale, ed. E. H. Weatherly, EETS OS 200 (London: Oxford University Press, 1936).

Troves, Chretien de, Erec and Enide, ed. and trans. C. W. Carroll (New York and London: Garland, 1987).

Vices and Virtues, ed. F. Holthauser, 2 vols, EETS OS 89, 159 (London: Oxford University Press, 1888, 1920).

\section{Studies}

Aers, David, 'The self mourning: reflections on Pearl', Speculum 68 (1993), 54-73.

Aers, David, 'Christianity for courtly subjects: reflections on the Gawain-poet', in Brewer and Gibson, Companion, pp. 91-101.

Anderson, Gary A., The Genesis of Perfection: Adam and Eve in Fewish and Christian Imagination (Louisville: Westminster John Knox, 2001).

Anderson, J. J., 'Gawain and the hornbook', Notes $\Xi^{\circ}$ Queries ns 37 (1990), 160-3.

Anderson, J. J., 'The three judgments and the ethos of chivalry in Sir Gawain and the Green Knight', Chaucer Review 24 (1990), 337-55.

Anderson, J. J., 'The narrators in the Book of the Duchess and the Parlement of Foules', Chaucer Review 26 (1992), 219-36.

Andrew, Malcolm, 'The realizing imagination in late medieval English narrative', English Studies 76 (1995), 113-28. 
Andrew, Malcolm, 'Theories of authorship', in Brewer and Gibson, Companion, pp. 23-33.

Arthur, Ross G., 'Gawain's shield as signum', in Blanch, Miller, and Wasserman, Text and Matter, pp. 221-7.

Barr, Helen, 'Pearl - or the jeweller's tale', Medium Avum 69 (2000), 59-79.

Bennett, Michael J., 'The historical background', in Brewer and Gibson, Companion, pp. 71-90.

Bishop, Ian, Pearl in its Setting (Oxford: Blackwell, 1968).

Blanch, Robert J., Miriam Youngerman Miller, and Julian N. Wasserman, eds, Text and Matter: New Critical Perspectives of the Pearl-Poet (Troy, New York: Whitston, 1991).

Blanch, Robert J. and Julian N. Wasserman, From Pearl to Gawain: Forme to Fynisment (Gainesville: Florida University Press, 1995).

Brewer, Derek and Jonathan Gibson, eds, A Companion to the Gawain-Poet (Cambridge: D. S. Brewer, 1997).

Burrow, J. A., A Reading of Sir Gawain and the Green Knight (London: Routledge and Kegan Paul, 1965).

Burrow, J. A., The Gawain-Poet (Tavistock: Northcote House, 2001).

Burrow, John, 'Honour and shame in Sir Gawain and the Green Knight', in his Essays in Medieval Literature (Oxford, 1984).

Carruthers, Leo, 'The Duke of Clarence and the earls of March: Garter Knights and Sir Gawain and the Green Knight', Medium AEvum 70 (2001), 66-79.

Cherry, John, The Middleham fewel and Ring (York: Yorkshire Museum, 1994).

Clark, S. L. and Julian N. Wasserman, 'Purity: the cities of the raven and the dove', American Benedictine Review 29 (1978), 285-6.

Cohen, Jeffrey J., Of Giants: Sex, Monsters, and the Middle Ages (Minneapolis: Minnesota University Press, 1999).

Condren, Edward I., The Numerical Universe of the Gawain-Pearl Poet (Gainesville: Florida University Press, 2002).

Cooper, Helen, 'The supernatural', in Brewer and Gibson, Companion, pp. 27791.

Davenport, W. A., The Art of the Gawain Poet (London: Athlone Press, 1978).

Davis, N., 'A note on Pearl', in John Conley, ed., The Middle English Pearl: Critical Essays (Indiana: Notre Dame University Press, 1970), pp. 325-34.

Fanger, Claire, ed., Conjuring Spirits: Texts and Traditions of Ritual Magic (Stroud: Sutton, 1998).

Farrell, Thomas J., ed., Bakhtin and Medieval Voices (Gainesville: Florida University Press, 1996).

Fein, S. G. The 'twelve-line stanza forms in Middle English and the date of Pearl', Speculum 72 (1997), 367-98.

Glenn, J. A., 'Dislocation of kynde in the Middle English Cleanness', Chaucer Review 18 (1984), 77-91.

Green, Richard Hamilton, 'Gawain's shield and the quest for perfection', English Literary History 29 (1962), 121-39, reprinted in Robert J. Blanch, ed. Sir Gawain and Pearl: Critical Essays (Bloomington: Indiana University Press, 1966), 176-94. 
Hardman, Phillipa, 'Gawain's practice of piety in Sir Gawain and the Green Knight', Medium Avvum 68 (1999), 247-67.

Heng, Geraldine, 'Feminine knots and the other in Sir Gawain and the Green Knight', PMLA 106 (1991), 500-14.

Hollis, Stephanie J., 'The pentangle knight: Sir Gawain and the Green Knight', Chaucer Review 15 (1981), 271-81.

Holquist, Michael, ed., The Dialogical Imagination: Four Essays [by M. M. Bakhtin], trans. Caryl Emerson and Michael Holquist (Austin: Texas University Press, 1981).

Horgan, A. D., 'Gawain's pure pentaungle and the virtue of faith', Medium Avvum 56(1987), 310-16.

Hulbert, J. R., 'A hypothesis concerning the alliterative revival', Modern Philology 28(1931), 405-22.

Ingledew, Francis, 'Liturgy, prophecy, and Belshazzar's Babylon: discourse and meaning in Cleanness', Viator 23 (1992), 247-79.

Kean, P. M., The Pearl: An Interpretation (London: Routledge and Kegan Paul, 1967).

Keen, Maurice, Chivalry (New Haven and London: Yale University Press, 1984).

Keiser, Elizabeth B., Courtly Desire and Medieval Homophobia: The Legitimation of Sexual Pleasure in Cleanness and Its Contexts (New Haven and London: Yale University Press, 1997).

Kieckhefer, Richard, Magic in the Middle Ages (Cambridge: Cambridge University Press, 1990).

Kieckhefer, Richard, 'The devil's contemplatives', in Fanger, Conjuring, pp. 25065.

Klaassen, Frank, 'English manuscripts of magic, 1300-1500: a preliminary survey', in Fanger, Conjuring, pp. 3-31.

Marks, Richard and Paul Williamson, Gothic: Art for England 1400-1547 (London: V\&A Publications, 2003).

Milroy, James, 'Pearl: the verbal texture and the linguistic theme', Neophtlologus 55 (1971), 195-208.

Morse, Charlotte C, 'The image of the vessel in Cleanness', University of Toronto Quarterly 40 (1971).

Morse, Charlotte C, The Pattern of Fudgment in the Queste and Cleanness (Columbia: Missouri University Press, 1978).

Muscatine, Charles, Poetry and Crisis in the Age of Chaucer (Notre Dame: Notre Dame University Press, 1972).

Nicholls, Jonathan, The Matter of Courtesy: Medieval Courtesy Books and the Gawain-Poet (Woodbridge: Boydell and Brewer, 1985).

Pearsall, Derek, 'Rhetorical descriptie in Sir Gawain and the Green Knight', Modern Language Review 50 (1955), 129-34.

Pearsall, Derek, 'Courtesy and chivalry in Sir Gawain and the Green Knight: the order of shame and the invention of embarrassment', in Brewer and Gibson, Companion, pp. 351-62.

Peters, Edward, The Magician, the Witch, and the Law (Philadelphia: Pennsylvania University Press, 1978). 
Powell, Susan M., 'Untying the knot: reading Sir Gawain and the Green Knight', in Susan M. Powell and Jeremy J. Smith, eds, New Perspectives on Middle English Texts (Cambridge: D. S. Brewer, 2000), pp. 55-74.

Prior, Sandra Pierson, The Fayre Formez of the Pearl Poet (East Lansing: Michigan state University Press, 1996).

Putter, Ad, Sir Gawain and the Green Knight and French Arthurian Romance (Oxford: Oxford University Press, 1995).

Putter, Ad, An Introduction to the 'Gawain'-Poet (London and New York: Longman, 1996).

Radulescu, Raluca L., The Gentry Context for Malory's Morte Darthur (Cambridge: Boydell \& Brewer, 2003).

Renoir, Alain, 'Descriptive techniques in Sir Gawain and the Green Knight', Orbis Litterarum 13 (1958), 126-32.

Rhodes, Jim, Poetry Does Theology: Chaucer, Grosseteste, and the 'Pearl'-Poet (Notre Dame: Notre Dame University Press, 2001).

Riddy, Felicity, 'Jewels in Pearl', in Brewer and Gibson, Companion, pp. 43-55.

Rigby, S. H., Chaucer in Context (Manchester: Manchester University Press, 1996).

Rooney, Anne, Hunting in Middle English Literature (Cambridge: D. S. Brewer, 1993)

Schleusener, Jay, 'Patience lines 35-40', Modern Philology 67 (1969), 64-6.

Spearing, A. C, Criticism and Medieval Poetry (London: Edward Arnold, 1964).

Spearing, A. C, The Gawain-Poet: A Critical Study (Cambridge: Cambridge University Press, 1970).

Spearing, A. C, 'Poetic identity', in Brewer and Gibson, Companion, pp. 35-51.

Stanbury, Sarah, Seeing the Gawain-Poet (Philadelphia: Pennsylvania University Press, 1991).

Stokes, Myra, 'Suffering in Patience', Chaucer Review 18 (1984), 354-63.

Thorndike, Lynn, A History of Magic and Experimental Science, 8 vols (New York: Columbia University Press, 1923-58).

Twomey, Michael W., 'The sin of untrawthe in Cleanness', in Blanch, Miller, and Wasserman, Text and Matter, pp. 117-45.

Twomey, Michael W., 'Morgain la Fee in Sir Gawain and the Green Knight: from Troy to Camelot', in Norris J. Lacy, ed., Text and Intertext in Medieval Literature', (New York: Garland, 1996), pp. 91-115.

Vitto, Cindy L., 'Feudal relations and reason in Cleanness', in Liam O. Purdon and Cindy L. Vitto, eds, The Rusted Hauberk: Feudal Ideals of Order and their Decline, (Florida: Florida University Press, 1994).

Wallace, David, 'Cleanness and the terms of terror', in Blanch, Miller, and Wasserman, Text and Matter, pp. 93-104.

Wallace, David, ed., The Cambridge History of Medieval English Literature (Cambridge: Cambridge University Press, 1995).

Watson, Nicholas, 'The Gawain-poet as a vernacular theologian', in Brewer and Gibson, Companion, pp. 293-313.

Watts, Ann Chambers, 'Pearl, inexpressibility, and poems of human loss', PMLA 99 (1984), 26-40.

Williams, David, 'The point of Patience', Modern Philology 68 (1970) 127-36.

Wilson, Edward, The Gawain-Poet (Leiden: Brill, 1976). 